\title{
Maintenance, Repair and Overhaul (MRO) Fundamentals and Strategies: An Aeronautical Industry Overview
}

\author{
Darli Rodrigues Vieira \\ Holds the research chair in Management of \\ Aeronautical Projects \\ Université du Québec à Trois Rivières - Canada
}

\author{
Paula Lavorato Loures \\ Management of Aeronautical Projects member \\ Université du Québec à Trois Rivières - Canada
}

\begin{abstract}
The purpose of this paper is to present the maintenance, repair and overhaul (MRO) and aeronautical industry literature review, providing insights related to strategies of MRO business models. The fundamentals of MRO services and the aeronautical industry have been identified through an extensive literature review. The impact of the MRO outsourcing model was then investigated from the perspective of each stakeholder (aircraft original equipment manufacturers - OEMs, repair shops, system suppliers and airlines) using a SWOT (strengths, weaknesses, opportunities and threats) analysis. First, MRO basic concepts were identified: how FAA (Federal Aviation Administration) classifies repair and how MRO is performed. This study also analyzed a simplified parts and MRO services flow in the aeronautical industry, characterizing two important stakeholders: customers and repair shops. Although the production parts purchasing process is fairly simple, the spare parts process requires more attention due to the many players involved. Finally, the SWOT analysis identified strong competition between stakeholders; however, the investigation indicates that there is a tendency for the market to build partnerships between stakeholders to expand market penetration.
\end{abstract}

\section{Keywords}

MRO; aeronautical industry; business model; outsourcing; airlines, repair shops

\section{INTRODUCTION}

Maintenance, repair and overhaul (MRO) in the aeronautical industry is a complex process that has strict and precise requirements defined by airworthiness authorities to guarantee the safety of passengers and aircrew. Billions of dollars are spent by airlines every year to comply with such requirements, which represent a relevant portion of their total operational costs. Despite the extensive market and process knowledge, MRO service is a world relatively unexplored by Aircraft Original Equipment Manufacturers (OEMs), such as Airbus, Boeing, Bombardier, Embraer, Gulfstream and others. Usually, contracts negotiated with System Suppliers are focused on the aircraft development and production, and they fail to take advantage of relevant aftermarket business opportunities. Due to the restrictions to certify an aircraft, the aeronautical supply chain base is very limited. Basically, system suppliers not only provide system/parts to the aircraft OEMs but also to their competitors as sub tier suppliers. This restricted suppliers' availability, if compared to, for example, the automotive industry, negatively impacts the negotiation results. In fact, OEMs are not alone in being affected by the lack of stronger commercial agreements covering MRO. To illustrate, the spare part prices paid by airlines, business jet owners and governments are significantly higher than the production prices, reflecting an expressive MRO cost for those organizations. Looking for opportunities to reduce costs and be more competitive, airlines are partially or fully outsourcing their MRO activities to repair shops, system suppliers and eventually aircraft OEMs. To help companies and the academic community better understand the above scenario, this paper presents the fundamentals of MRO and the aeronautical market. Then, airlines' MRO outsourcing business models are identified and discussed. Finally, a SWOT (strengths, weaknesses, opportunities and threats) analysis is developed to examine the MRO business models' strategies from the perspective of airlines, aircraft OEMs, system suppliers and repair shops.

\section{LITERATURE REVIEW}

\subsection{Maintenance, Repair and Overhaul (MRO) Fundamentals}

MRO may be defined as "all actions that have the objective of retaining or restoring an item in or to a state in which it can perform its required function. The actions include the combination of all technical and corresponding administrative, managerial, and supervision actions" [1]. Kinnisson [2] states that maintenance can be described as the process of ensuring that a system continually performs its intended functions at its original level of reliability and safety. Viles et al. [3] emphasize the goal of maintenance is not only to reduce repair time but also to improve product reliability, as well as to capture relevant information for analysis. "Maintaining complex systems such as aircraft fleets, rail systems, and production facilities can often exceed the cost of research, development, and production" [4]. "The aircraft fleet maintenance plays the most important role to guarantee the safety and reliability of the fleet in commercial airlines and military air forces" [5]. "Maintenance plays an important role in keeping product availability, reliability and quality at an appropriate level. It also addresses the product safety requirements" [6].

The importance of MRO can be judged by the fact that it typically constitutes $12-15$ per cent of an airline's operating cost [7], with annual expenditures estimated to be US $\$ 50$ billion in 2013 [8] and employment of 480,000 people in the world [9]. Phillips et al. [10] explain that the record aircraft production following strong sales in 2006 and 2007, given the typical 18,000 -cycle or 8-10 years between overhauls, has created an unprecedented demand for landing gear overhauls on both long and short-haul aircraft. McFadden and Worrells [11] state that the worldwide MROs have grown in response to continuous and increasing demand into a viable segment of the aviation industry. Finally, CIMData [12] highlights that the profitability of the industry is not from the sale of aircraft, but from maintenance for an anticipated thirty-plus year lifespan.

The MRO in the aerospace market is a complex process that has strict and precise requirements to guarantee the safety of 
passengers and aircrew. Phillips et al. [10] corroborate that maintenance forms an essential part of aircraft airworthiness criteria; its main objective is to ensure a fully serviced, operational and safe aircraft. Proper maintenance is an essential contributor to the high levels of safety experienced today; in contrast, improper maintenance can have tragic effects [13]. Pipame [9] explains that to maintain and repair their equipment, airlines take into account the manufacturers' instructions and standards of international organizations to improve the quality and safety of flight. "A number of entrepreneurial operators and support providers have adopted a new group of postproduction support strategies. Although there has been a considerable amount of improvement in the quality and reliability of components and systems, as well as in materials and procedures, over the 100-year life of aviation, they still have not reached total perfection. Aviation equipment, no matter how good or how reliable, still needs attention from time to time" [2]. Marais et al. [13] emphasize that increasing the level of investigation surrounding aviation incidents is recommended for improved safety. Marais et al. [13] also agree with many of the FAA (Federal Aviation Administration) incident reports which simply state that a particular component failed and more detailed investigations would reveal the root causes of component failures and would, as suspected, identify inadequate maintenance to be an important factor.

Regarding in-house airline maintenance capabilities, Carpenter and Henderson [14] explain that commercial airlines can establish MRO services in their own fleets and operate as profit centers; however, it is not uncommon for airline operators to spin-off these MROs and act as a separate, corporate activity. "Third Party Independents perform similar functions as In-house MROs but are not affiliated to an airline operator. Independents often provide these services at a lower price. Therefore, independents market themselves as the value proposition over the OEMs and In-house MROs" [14].

Analyzing the operation side, Kinnisson [2] explains that aircraft maintenance can be divided into scheduled and unscheduled maintenance. Scheduled maintenance is a preventive action to ensure that a product functions properly at pre-set intervals. Unscheduled maintenance is not planned or programmed, but it is required when an item has failed or broken down. Kinnisson [2] and authors clarify that scheduled maintenance includes routine and detailed inspections called transit, 48 h, "A", "B", "C" and "D" checks, subdivided in line and base categories, as detailed in Table 1 .

According to Yoon [15], maintenance can be carried out either on or off the aircraft. When off-aircraft maintenance is performed, the equipment and components are removed from the aircraft and replaced with serviceable units. The removed units are then modified into materials for replacement and routed to the repair facility. The pace may be slower than onaircraft maintenance, but its short turnaround for maintenance (meaning time to repair), is important and sometimes necessary.

The Aviation Safety Bureau [16] describes different types of aircraft repair:
(1) Aircraft Structural Repairs: structural repairs are made to aircraft that have sustained damage to the structure (i.e., external skin, stringers, formers, bulkheads, etc.). There are several ways an aircraft structure can be damaged. It is usually caused by ground service equipment, maintenance stands, bird strikes, or lightning strikes.

(2) Component repairs: component repairs range from simple part replacements to an entire overhaul. If a component fails to operate properly, it is removed from the aircraft and replaced by one that operates properly. The removed component is then repaired.

Miroux [17] explains that MRO management has become more complex due to business growth, specialization and diversity: cheap vs. expensive, none or slow movers vs. high movers, repairable vs. consumable, critical vs. non critical, standard vs. specific, and supplier lead times. The complexity of MRO management, which requires in-depth and specialized expertise to handle inventory management, forecasting, supply management, return and repair flows etc., forces companies to rethink their MRO strategies. Karadžic et al. [18] state that due to the high intensive workforce industry, attracting and maintaining technically proficient workers is one of the many challenges. To obtain cost savings and improve reliability, airlines are outsourcing partial or full MRO management to third party companies [17]. This situation will be more deeply analyzed in Section $3-$ MRO Business Models.

\subsection{Particularities of the Aeronautical Industry}

The supply chain in the aeronautical industry is very complex [19]. Each component of an aircraft must be certified by the airworthiness authorities, which define strict requirements to guarantee safety. Due to the high level of requirements to qualify a supplier, there is a very limited number of companies authorized to provide parts and services in the aeronautical industry. This predicament leads to limited options when selecting a supplier for a new aircraft program and results in a lack of leverage to negotiate commercial conditions. Additionally, the same system suppliers operate in different sub tiers, so they become suppliers of their competitors, which may negatively impact the relationship between them and, ultimately, the final customer.

Figure 1 reflects the above scenario, showing production and spare parts and the MRO services flow in the aeronautical industry. Essentially, there are four stakeholders: sub tier suppliers/ suppliers, aircraft OEMs, customers and MRO repair shops. The business model recently applied by aircraft OEMs provides for key suppliers working as system integrators. This means that instead of having hundreds of suppliers to address, aircraft OEMs have approximately 50 system suppliers. They can produce or purchase from multiple suppliers and be responsible for delivering an integrated system. Raju et al. [20] corroborate that the modern day military and commercial aircraft systems are an integration of a large number of sub-systems and components. 
Table 1: Detailed Scheduled Maintenance Source: Kinnisson [2] and authors.

\begin{tabular}{|c|c|c|c|c|}
\hline $\begin{array}{c}\text { Maint } \\
\text { enanc } \\
\text { e }\end{array}$ & Check & $\begin{array}{l}\text { When (an } \\
\text { average) }\end{array}$ & Description & Examples \\
\hline \multirow{3}{*}{ Line } & $\begin{array}{l}\text { Transi } \\
\text { t, } \\
\text { daily } \\
\text { or } 48 \\
\mathrm{~h}\end{array}$ & $\begin{array}{l}\text { After each } \\
\text { stop or } \\
\text { when } \\
\text { aircraft is on } \\
\text { ground } \\
\text { more than } 4 \\
\text { hours }\end{array}$ & $\begin{array}{l}\text { Normally includes a visual inspection of the } \\
\text { aircraft to look for obvious damage and } \\
\text { deterioration. }\end{array}$ & $\begin{array}{l}\text { Check fluid levels and emergency equipment, } \\
\text { inspect wheels and brakes. }\end{array}$ \\
\hline & A & $\begin{array}{l}500 \mathrm{FH} \text { or } 2 \\
\text { months }\end{array}$ & $\begin{array}{l}\text { Accomplished at a designated maintenance } \\
\text { station and includes the opening of access } \\
\text { panels to check and service certain items. } \\
\text { Some limited special tooling, servicing, and } \\
\text { test equipment is required. }\end{array}$ & $\begin{array}{l}\text { General external visual inspection of aircraft } \\
\text { structure for evidence of damage, deformation, } \\
\text { corrosion, missing parts; crew oxygen system } \\
\text { pressure check; operationally check emergency } \\
\text { lights; lubricate nose gear retract actuator; } \\
\text { check parking brake accumulator pressure; } \\
\text { perform Built-in Test Equipment (BITE) test } \\
\text { of Flap/Slat Electronics Unit. }\end{array}$ \\
\hline & $\bar{B}$ & $1100 \mathrm{FH}$ or & \multicolumn{2}{|c|}{$\begin{array}{l}\text { This is a slightly more detailed check of components and systems. Special equipment and tests } \\
\text { may be required. It does not involve detailed disassembly or removal of components. }\end{array}$} \\
\hline \multirow[t]{2}{*}{ Base } & $\mathrm{C}$ & $\begin{array}{l}\text { Every } 4000 \\
\text { FH or } 20 \\
\text { months }\end{array}$ & $\begin{array}{l}\text { This is an extensive check of individual } \\
\text { systems and components for serviceability } \\
\text { and function. It requires a thorough visual } \\
\text { inspection of specified areas, components } \\
\text { and systems as well as operational or } \\
\text { functional checks. It is a high-level check } \\
\text { that involves extensive tooling, test } \\
\text { equipment, and special skill levels. 'C' checks } \\
\text { remove the airplane from the revenue } \\
\text { schedule for } 3 \text { to } 5 \text { days. The 'C' check } \\
\text { includes the lower checks, i.e., 'A,' 'B,' and } \\
\text { Daily checks. }\end{array}$ & $\begin{array}{l}\text { Visually check flight compartment escape } \\
\text { ropes for condition and security; check } \\
\text { operation of DC bus tie control unit; visually } \\
\text { check the condition of entry door seals; } \\
\text { operationally check flap asymmetry system; } \\
\text { pressure decay check APU fuel line shroud; } \\
\text { inspect engine inlet TAI ducting for cracks. }\end{array}$ \\
\hline & $\begin{array}{l}\mathrm{D} / \\
\mathrm{HMV}\end{array}$ & $\begin{array}{l}25000 \mathrm{FH} \\
\text { or } 6 \text { years }\end{array}$ & $\begin{array}{l}\text { This can also be referred to as the structural } \\
\text { check. It includes detailed visual and other } \\
\text { non-destructive test inspections of the aircraft } \\
\text { structure. It is an intense inspection of the } \\
\text { structure for evidence of corrosion, structural } \\
\text { deformation, cracking, and other signs of } \\
\text { deterioration or distress and involves } \\
\text { extensive disassembly to gain access for } \\
\text { inspection. Special equipment and techniques } \\
\text { are used. Structural checks are man-hour and } \\
\text { calendar-time intensive. The 'D' check } \\
\text { includes the lower checks, i.e., 'A,' 'B,' 'C,' } \\
\text { and daily checks. This check removes the } \\
\text { airplane from service for } 20 \text { or more days. }\end{array}$ & $\begin{array}{l}\text { Inspect stabilizer attach bolts; inspect floor } \\
\text { beams; detailed inspection of wing box } \\
\text { structure. }\end{array}$ \\
\hline
\end{tabular}




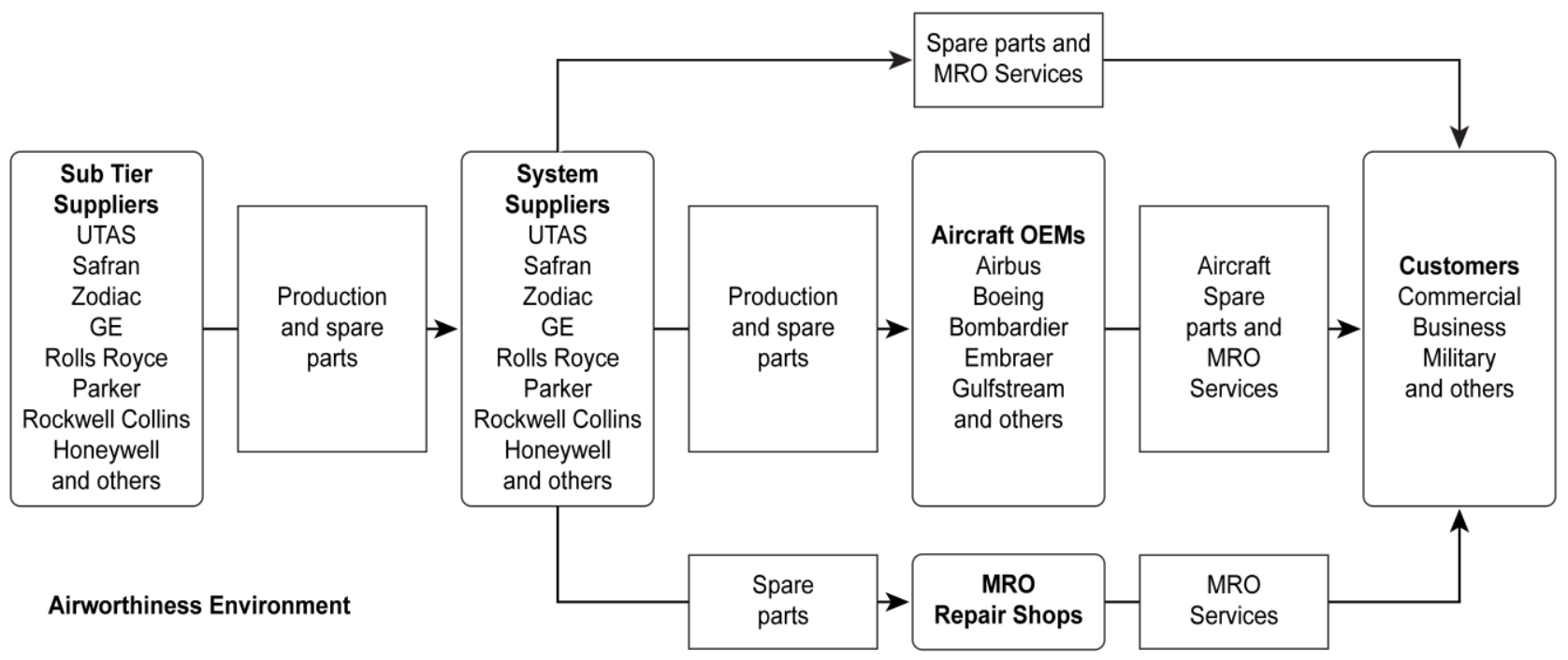

Figure 1: Simplified parts and MRO services flow in the aeronautical industry. Source: Authors.

With regards to production parts, the process is fairly simple. The aircraft OEM places a purchasing order with the system supplier, respecting the lead-time and other commercial agreements. The part is delivered and the process is closed. The process is more complex when it pertains to spare parts. The customer can place a purchasing order to numerous players - aircraft OEM, repair shops and even directly to the system suppliers. In addition, the customer can request MRO services, especially heavy maintenance, from repair shops, system suppliers, and more recently from aircraft OEMs.

This study focuses on customers and MRO repair shops to provide more detailed information. Future papers will address additional stakeholders and provide a broader review of information.

\subsubsection{Customer}

\subsubsection{Commercial Aviation Industry}

The commercial aviation industry is composed of airline companies that offer passenger and cargo transportation services. Approximately 230 major airlines operate throughout the world and are registered with the International Air Transport Association (IATA).

Boeing [21] explains that the industry continuously adapts to various market forces. Key market forces that impact the airline industry are fuel prices, economic growth and development, environmental regulations, infrastructure, market liberalization, airplane capabilities, other modes of transport, business models, and emerging markets. Each of these forces can have both positive and negative impacts on the industry. Fuel has become the largest component of an airline's cost structure. This has driven manufacturers to produce more fuel-efficient airplanes and has forced airlines to pursue cost reductions and revenue enhancements in other areas to maintain profitability, even with higher fuel costs.

Boeing [21] also clarifies that commercial aviation has weathered many downturns in the past. However, recovery has followed quickly as the industry reliably returned to its long-term growth rate of approximately 5 percent per year. Despite uncertainties, 2012 passenger traffic rose 5.3 percent from 2011 levels. Boeing expects this trend to continue over the next 20 years, with world passenger traffic growing 5.0 percent annually. Air cargo traffic has been fluctuating after a high period in 2010 . Air cargo decreased by 1.5 percent in
2012. The expansion of emerging-market economies will, however, foster a growing need for fast, efficient transportation of goods. Today, the fleet size in operation is approximately 20,000 aircraft and it is expected that this number will double over the next 20 years. An increase in the demand of fleet size and passenger/cargo directly impacts the MRO demand.

\subsubsection{Business Aviation Industry}

Worldwide demand for business jets is highly correlated with wealth creation, which, in turn, is largely driven by economic growth. Since the introduction of the business jet, in 1965, the business aircraft market has been highly cyclical. The crisis in the financial markets at the end of 2008 precipitated a sharp downturn in business aviation and new business aircraft orders. Bombardier estimates that more than 800 orders across all manufacturers were cancelled in the Light to Large categories in 2009 [22].

Bombardier [22] predicts 24,000 business jet deliveries valued at $\$ 650$ billion in a 20 -year delivery forecast. Bombardier also anticipates 9,800 deliveries worth $\$ 269$ billion from 2013 to 2022 , and 14,200 deliveries worth $\$ 381$ billion from 2023 to 2032, which consequently contribute to an increase in MRO demand.

\subsubsection{Military Aviation Industry}

Political decisions determine when and how the military, as a whole, will be employed and this employment has a direct impact on the MRO industry [23]. Traditionally, North America and Europe accounted for approximately $80 \%$ of global defense spending. However, the global economic downturn, the US economic crisis, and the European debt crisis are expected to negatively impact defense spending and lead to defense budget cuts. As a consequence, the allocation for military aircraft is not expected to grow significantly during the forecast period due to financial constraints faced by most of the leading defense spenders [24]. In 2008, the global military aircraft inventory exceeded 39,000 aircraft with maintenance on these aircraft costing governments $\$ 60.7$ billion [25]. The U.S. accounted for half of this, spending an estimated $\$ 31$ billion on military MRO in 2008. The next largest individual country was Japan, which spent an estimated \$2.5 billion during this period [23]. Canada has maintained a fleet of CF-18 in service since 1982. Extensive maintenance was conducted to extend the aircraft life span, 
repair any structural damage and modernize the entire system. Because spare parts will be increasingly rare and expensive, the systems will become more obsolete, and the CF-18 will be less compatible with other fleets. Canada is analyzing the purchase of F-35 to replace the fighter aircraft [26]

\subsubsection{MRO Repair Shops}

Most major aircraft maintenance and repair work is provided by repair shops, which carry out MRO operations for the aircraft operators [10]. According to Pipame [9], 80\% of MRO repair shops are small and medium enterprises. "Heavy airframe maintenance, which is especially labor intensive, offers an opportunity to reduce costs by off-shoring into lower wage countries such as Eastern Europe and Asia" [27]. According to Aviation Week and Space Technology (AW\&ST) [8], the market is actually dominated by Asian companies and the majority of the top 10 MRO global leading players are indeed in this geographic area, as demonstrated in Table 2. Singapore Technologies Aerospace is the largest airframe maintenance company in the world, having accumulated 11.5 million maintenance man-hours in 2012, followed by Haerco Group, from Hong Kong, which had 7.4 million maintenance man-hours. Lufthansa Technik, the largest airframe maintenance company in years past, has lost market share and is now in fifth place.

MRO providers are expanding their geographical reach and capabilities in a bid to become regional and global full service providers [10]. The number of MRO businesses in emerging countries is increasing due to low labor costs and joint ventures between system suppliers and aircraft manufacturers. Some examples are Pratt \& Whitney and China Eastern, General Electric and Singapore Technologies Aerospace, Boeing and Shanghai Aviation Services Co., and Bombardier and Tianjin Airport.

Table 2: The MRO global leading players Source: Adapted from AW\&ST [8]

\begin{tabular}{|c|c|c|c|}
\hline \multicolumn{2}{|r|}{ Company } & Man/hours & Country \\
\hline 1 & $\begin{array}{l}\text { Singapore } \\
\text { Technologies } \\
\text { Aerospace }\end{array}$ & 11.5 million & Singapore \\
\hline 2 & Haeco Group & 7.4 million & Hong Kong \\
\hline 3 & AAR Corp. & 4.6 million & USA \\
\hline 4 & $\begin{array}{l}\text { SIA Engineering } \\
\text { Co. }\end{array}$ & 4.2 million & Singapore \\
\hline 5 & Lufthansa Technik & 4.1 million & Germany \\
\hline 6 & AFI KLME\&M & 3.9 million & Holland/France \\
\hline 7 & $\begin{array}{l}\text { Timco Aviation } \\
\text { Services }\end{array}$ & 3.2 million & USA \\
\hline 8 & Ameco Beijing & 2.8 million & China \\
\hline 9 & $\begin{array}{l}\text { Mubadala } \\
\text { Aerospace }\end{array}$ & 2.5 million & $\begin{array}{l}\text { United Arab } \\
\text { Emirates }\end{array}$ \\
\hline 10 & Iberia Maintenance & 2.3 million & Spain \\
\hline
\end{tabular}

\section{MRO BUSINESS MODELS}

Almeida [28] explains how an airline makes the decision whether to manage MRO in-house or to outsource it to define the strategies for the right MRO service at the best cost. Low cost carriers are particularly looking to outsource MRO activities to reduce their operational costs. Rosenberg [29] indicates the trend toward outsourcing is increasing and this figure is expected to increase to 65 per cent of the MRO budget by 2010 .

The outsourcing and offshoring of activities such as aircraft maintenance can result in a number of advantages for airlines.
Contractors may provide access to specialized skills that are not available within the principal organization and economies of scale may be generated by the creation of a hub of skilled workers, job opportunities and knowledge generation for innovation. The greater volume of work in repair stations can enhance the speed of task completion. In addition, outsourcing may be used when demand exceeds the baseline capacity of in-house maintenance [30]. Airlines can take advantage of outsourcing non-core intensive labor activities and focus on fewer value-added MRO activities [29]. Miroux [17] emphasizes that the MRO strategy must be aligned with the firm's overall strategy and must sustain the long-term business, following the framework presented in Figure 2. The framework explains key elements, such as budget and service level, to be considered when making the outsourcing decision.

Outsourcing is often seen as a critical business capability that enhances a company's overall profitability [17]. Al-kaabi et al. [31] identified different MRO models based on the study of different airline MRO structures in the literature. Each airline has its own characteristics and different levels of outsourcing. These models are fully integrated, partially outsourced, mostly outsourced and wholly outsourced, and they are illustrated in Figure 3.

In the Fully Integrated MRO model, all MRO activities are provided internally; in addition, the airline's capabilities are extended to support other airlines. While many airlines have treated MRO as an expense, other airlines have successfully transformed their MRO into a profit generation units. In the Partially Outsourced MRO model, airlines try to maintain most of their MRO needs internally. A few activities are outsourced, but may be considered for managing in-house at a later stage. In the Mostly Outsourced MRO model, the airlines' MRO needs are outsourced and only critical activities are performed internally. The Wholly Outsourced MRO model contemplates outsourcing of all MRO activities. It is very similar to the Virtual Airline model, which considers MRO as a non-core activity. This model provides an airline with the opportunity to focus on its core competency of flying passengers, while non-core activities such as MRO are outsourced [32].

Al-kaabi et al. [31] corroborate that critical MRO activities such as line maintenance are frequently in-sourced, while activities with low demand at an airline level such as engine maintenance are often outsourced. The outsourcing decision is very much influenced by what is considered by the airline as a core competency as well as what level of criticality is associated with each MRO activity. While many airlines have considered MRO as a non-core activity, others have invested and expanded their MRO function [33]. In that case, when an airline decides to invest in internal MRO activities, the service can be extended to other airlines to reduce costs and increase revenues.

According to each market scenario (e.g., GDP, technological aids, labor issues, work scalability, unions), maintenance activity could be correlated with a specific economy type [28] as described in Table 3. Whereas economies of scale benefit an incumbent when the average cost falls as output increases, economies of scope arise when joint production of two or more related services can be achieved at a lower unit cost than when these services are produced separately. Alternatively, economies of density or location arise when it costs less for an incumbent to increase output in an existing network than for a competitor to enter the same market [28]. According to Collier [34], with proper oversight, quality of work and value of labor, an outsourcing practice can be extremely attractive. 
He observes "it is specialization and economies of scale, not just cheap labor, that provide the opportunity for companies to provide economical maintenance".

Table 3: Outsourcing reasons. Source: Almeida [28].

\begin{tabular}{|c|c|c|}
\hline Economy & Characteristics & $\begin{array}{c}\text { Maintenance } \\
\text { type }\end{array}$ \\
\hline Of scale & $\begin{array}{ll}- & \begin{array}{l}\text { Brings large volumes } \\
\text { together }\end{array} \\
- & \text { Maximizes heavy } \\
\text { investment } \\
-\quad & \text { Uses technology } \\
\text { advantages } \\
- & \text { Streamline process }\end{array}$ & $\begin{array}{ll}- & \text { Engine } \\
\text { overhaul } \\
\text { - } & \text { Component } \\
\text { maintenance }\end{array}$ \\
\hline Of scope & $\begin{array}{l}\text { - Uses low labor cost } \\
\text { platform }\end{array}$ & $\begin{array}{ll}- & \text { Heavy } \\
& \text { maintenance }\end{array}$ \\
\hline
\end{tabular}

\begin{tabular}{|c|cl|l|}
\hline & - & $\begin{array}{l}\text { Requires less } \\
\text { investment } \\
\text { Network close to } \\
\text { customers } \\
\text { Tunes products and } \\
\text { services at an } \\
\text { equable quality }\end{array}$ & \\
\hline Of & - & $\begin{array}{l}\text { Depends on airline } \\
\text { operation } \\
\text { Local platforms/cost } \\
\text { environment } \\
\text { Reduces necessary } \\
\text { costs by efficiency }\end{array}$ & - \\
& $-\begin{array}{l}\text { Line } \\
\text { maintenance }\end{array}$ \\
\hline
\end{tabular}

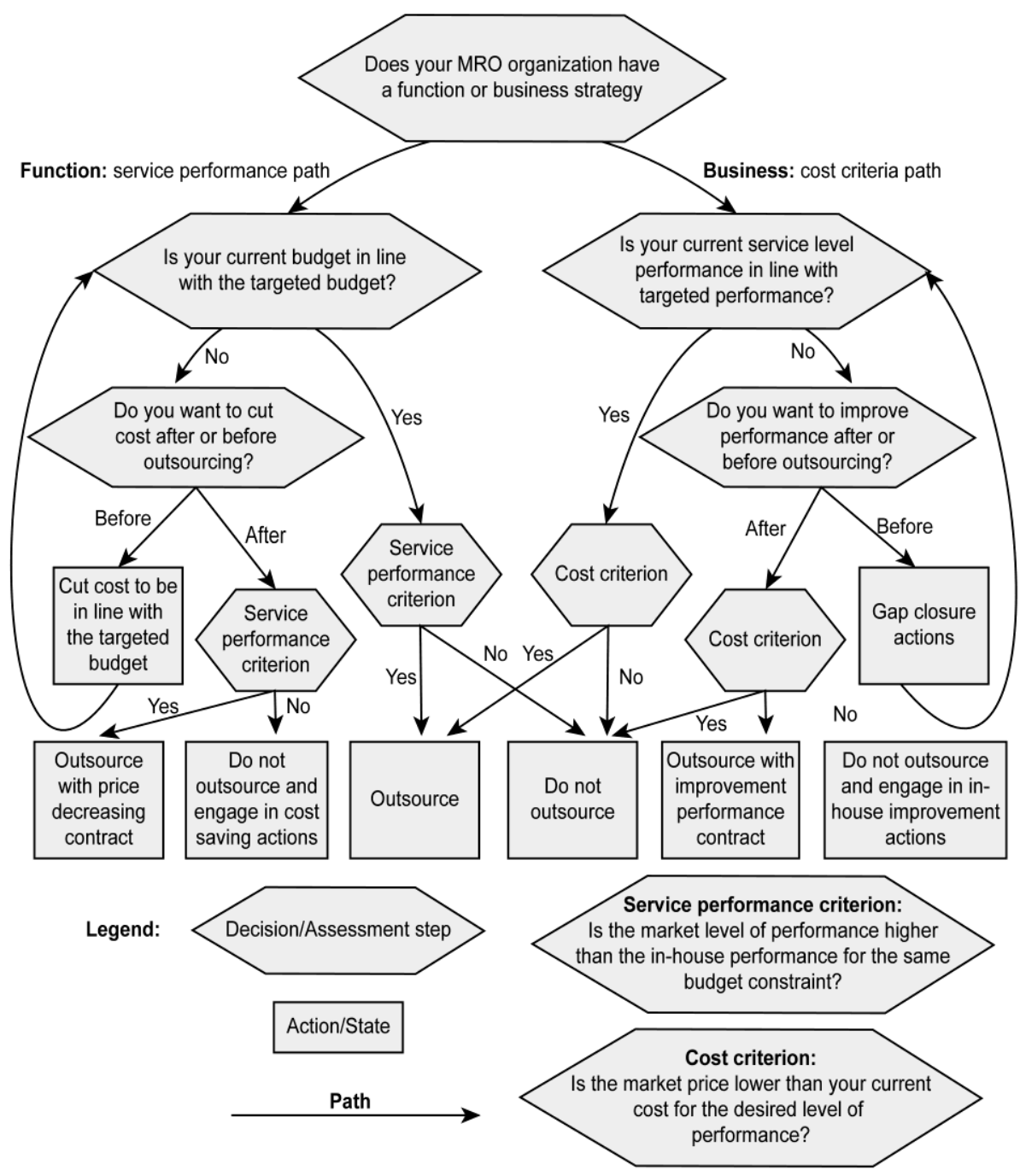

Figure 2: The outsourcing decisions tree integrating the outsourcing strategy, situation and management desires. Source: Miroux [17]. 


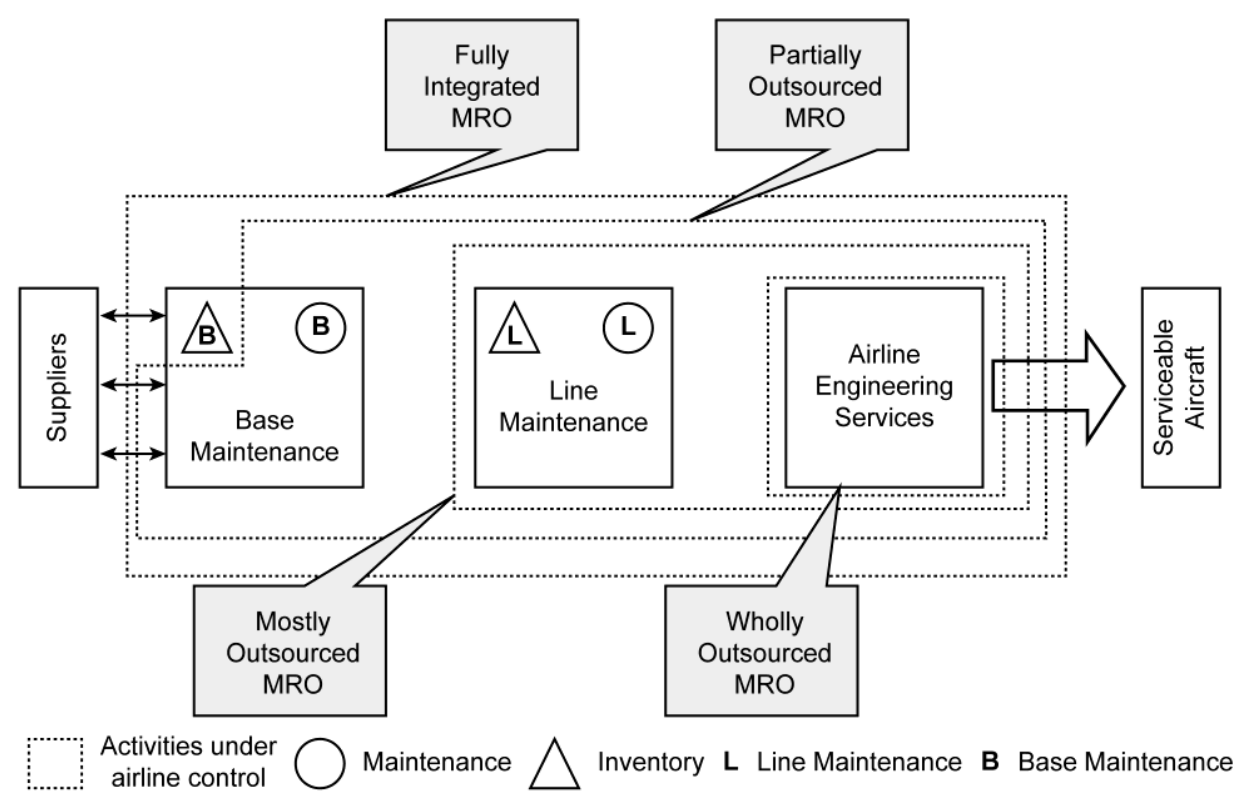

Figure 3: Airlines MRO models. Source: Al-kaabi et al. [31]. Reprinted with permission from Emerald Group Publishing Limited, originally published in Journal of Quality in Maintenance Engineering, Vol. 13 (3): 217-227, @ Emerald Group Publishing Limited [2007], http://www.emeraldinsight.com/doi/abs/10.1108/13552510710780258

To reduce costs, an airline company can outsource the MRO service to a repair shop, a system supplier or, more recently, to an aircraft OEM. Based on five industry specialists' feedback, Table 4 presents a SWOT (strengths, weaknesses, opportunities and threats) analysis of the MRO business using each stakeholder's perspective.

This exercise shows the strong competition between stakeholders due to the relevant number of players. Thousands of repair shops operate around the world, and systems suppliers are becoming stronger because of the partnerships with each other and aircraft OEMs, which expands their market penetration.

One critical fact is that customers seek a "one stop shop" solution when overhaul time is extensive. This preference indicates that customers do not want to overhaul the engine in one place and the landing gear in another. It is preferred that all services be provided in only one location. This circumstance impacts the business of small companies

Table 4: SWOT Analysis of MRO business from the perspective of each stakeholder. Source: Autors.

\begin{tabular}{|c|c|c|c|c|c|}
\hline $\begin{array}{l}\text { Stakeho } \\
\text { lders }\end{array}$ & $\begin{array}{c}\text { Strengt } \\
\text { hs }\end{array}$ & $\begin{array}{c}\text { Weakn } \\
\text { ess }\end{array}$ & $\begin{array}{c}\text { Opportu } \\
\text { nities }\end{array}$ & Threats & $\begin{array}{c}\text { Exampl } \\
\text { es }\end{array}$ \\
\hline $\begin{array}{l}\text { Airframe } \\
\text { OEMs }\end{array}$ & $\begin{array}{l}\text { Consoli } \\
\text { date } \\
\text { custome } \\
r \\
\text { relations } \\
\text { hip }\end{array}$ & $\begin{array}{l}\text { Contrac } \\
\text { ts } \\
\text { negotiat } \\
\text { ed with } \\
\text { supplier } \\
\text { s are } \\
\text { focused } \\
\text { on } \\
\text { producti } \\
\text { on. The } \\
\text { benefits } \\
\text { in the } \\
\text { afterma } \\
\text { rket are } \\
\text { scarce }\end{array}$ & $\begin{array}{l}\text { Partnersh } \\
\text { ip with } \\
\text { suppliers } \\
\text { and } \\
\text { companie } \\
\text { s located } \\
\text { in } \\
\text { emerging } \\
\text { countries } \\
\text { to } \\
\text { develop } \\
\text { their } \\
\text { capability } \\
\text { for MRO } \\
\text { services }\end{array}$ & $\begin{array}{c}\text { Investm } \\
\text { ent } \\
\text { required } \\
\text { in the } \\
\text { develop } \\
\text { ment of } \\
\text { repair } \\
\text { shops } \\
\text { and may } \\
\text { not be } \\
\text { able to } \\
\text { acquire } \\
\text { the } \\
\text { market } \\
\text { (e.g., } \\
\text { price } \\
\text { non- }\end{array}$ & $\begin{array}{l}\text { Boeing, } \\
\text { Airbus, } \\
\text { Bombar } \\
\text { dier, } \\
\text { Embraer } \\
\text { Gulfstre } \\
\text { am, etc. }\end{array}$ \\
\hline
\end{tabular}

\begin{tabular}{|c|c|c|c|c|c|}
\hline & & & & $\begin{array}{l}\text { competi } \\
\text { tive) }\end{array}$ & \\
\hline $\begin{array}{c}\text { Repair } \\
\text { shops }\end{array}$ & $\begin{array}{c}\text { They } \\
\text { already } \\
\text { know } \\
\text { the } \\
\text { market } \\
\text { and } \\
\text { have } \\
\text { expertis } \\
\text { e to } \\
\text { repair } \\
\text { parts }\end{array}$ & $\begin{array}{c}\text { The } \\
\text { largest } \\
\text { majorit } \\
\text { y does } \\
\text { not } \\
\text { work on } \\
\text { the } \\
\text { heave } \\
\text { mainten } \\
\text { ance }\end{array}$ & $\begin{array}{c}\text { Specializ } \\
\text { ation in a } \\
\text { market } \\
\text { segment } \\
\text { and } \\
\text { agreemen } \\
\text { t on } \\
\text { partnersh } \\
\text { ips with } \\
\text { others } \\
\text { players }\end{array}$ & $\begin{array}{c}\text { Very } \\
\text { competi } \\
\text { tive } \\
\text { market } \\
\text { (thousa } \\
\text { nds of } \\
\text { repair } \\
\text { ships } \\
\text { around } \\
\text { the } \\
\text { world) }\end{array}$ & $\begin{array}{c}\begin{array}{c}\text { Singapo } \\
\text { re }\end{array} \\
\text { technolo } \\
\text { gies, } \\
\text { Haerco, } \\
\text { Lufthan } \\
\text { sa, } \\
\text { Technik }\end{array}$ \\
\hline $\begin{array}{c}\text { System } \\
\text { suppliers }\end{array}$ & $\begin{array}{c}\text { Contract } \\
\text { closes } \\
\text { with } \\
\text { airframe } \\
\text { OEMs } \\
\text { benefit } \\
\text { supplier } \\
\text { s in the } \\
\text { aftermar } \\
\text { ket'; } \\
\text { large } \\
\text { knowled } \\
\text { ge base }\end{array}$ & $\begin{array}{c}\text { Restrict } \\
\text { ed to } \\
\text { the only } \\
\text { system } \\
\text { that it is } \\
\text { delivere } \\
\text { d }\end{array}$ & $\begin{array}{c}\text { Partnersh } \\
\text { ip with } \\
\text { aircraft } \\
\text { OEMs to } \\
\text { expand }\end{array}$ & $\begin{array}{c}\text { OEM } \\
\text { and } \\
\text { airlines } \\
\text { market } \\
\text { penetrat } \\
\text { ion }\end{array}$ & $\begin{array}{c}\text { System } \\
\text { supplier } \\
\text { s } \\
\text { (landing } \\
\text { gear, } \\
\text { avionics } \\
, \\
\text { hydrauli } \\
\text { cs, etc.) } \\
- \\
\text { Goodric } \\
\text { h, GE, } \\
\text { Messier- } \\
\text { Dowty }\end{array}$ \\
\hline Airlines & $\begin{array}{c}\text { Better } \\
\text { control } \\
\text { of MRO } \\
\text { activitie } \\
\text { s; large } \\
\text { knowled } \\
\text { ge base }\end{array}$ & $\begin{array}{c}\text { Inflexib } \\
\text { le } \\
\text { structur } \\
\text { e }\end{array}$ & $\begin{array}{c}\text { Use of } \\
\text { capabiliti } \\
\text { es and } \\
\text { expertise } \\
\text { to } \\
\text { expand; } \\
\text { focus on } \\
\text { new } \\
\text { markets; } \\
\text { partnersh } \\
\text { ip with } \\
\text { OEMs }\end{array}$ & $\begin{array}{c}\text { MRO } \\
\text { fluctuati } \\
\text { ng } \\
\text { demand } \\
\text { s; OEM } \\
\text { market } \\
\text { penetrat } \\
\text { ion; } \\
\text { new } \\
\text { technol } \\
\text { ogy } \\
\text { adaptati } \\
\text { on }\end{array}$ & $\begin{array}{c}\text { Large } \\
\text { airlines } \\
\text { that } \\
\text { have } \\
\text { their } \\
\text { own } \\
\text { MRO } \\
\text { structure } \\
- \\
\text { America } \\
\text { n } \\
\text { Airlines, } \\
\text { Delta, } \\
\text { United }\end{array}$ \\
\hline
\end{tabular}


Aircraft OEMs are providing MRO services to the market, and this may be a game changer for the future of the industry. Guimarães, J. E. Pécora Jr., and Vieira, D. R. [35] explain that a good example of companies making an effort to close their supply chain cycle are those that switch their core business from production to service. An example of this is copier manufacturers who, a couple of years ago, sold their machines, thus making the client responsible for the machine at the end of its life. Today, they rent or lease copy machines, which changed their core business and created the need for a reverse channel; the producer has now become responsible for the machine at the end of its productive life. Will this situation be the rule for aerospace industry in the future? Will airlines buy a full package from aircraft OEM, which includes the aircraft and all associated services? What can be accomplished now in terms of negotiation strategies to guarantee competitiveness in the future? Future studies will be focused on answers for such questions.

\section{CONCLUSIONS}

The purpose of this paper is to present the maintenance, repair and overhaul (MRO) and aeronautical industry literature review, as well as to provide insights related to MRO business models' strategies.

First, this study identified MRO basic concepts as important objectives: how FAA (Federal Aviation Administration) classifies repair and how MRO is performed. One critical issue is the safety orientation of all aeronautical markets. The aircraft airworthiness requirements underscore proper maintenance, which is an essential contributor to the high levels of safety.

The second section of this study analyzed a simplified parts and MRO services flow in the aeronautical industry, characterizing two important stakeholders: customers and repair shops. Although the production parts purchasing process is fairly simple, the spare parts process requires more attention due to the many stakeholders. Since airlines are seeking opportunities to reduce costs, parts and services can be purchased from different organizations, creating opportunities, especially for aircraft OEMs, which are in the process of increasing their participation in the MRO market. Because airlines are increasingly outsourcing their MRO activities (partially, mostly or completely outsourced) an opportunity is created for other stakeholders to increase their market share.

The third section presented a decision tree integrating the outsourcing strategy, showing that key elements, such as cost and customer satisfaction, need to be considered when determining whether to outsource MRO services. Additionally, a comparative analysis exposed how economies of scale, scope and location can be achieved depending on the MRO service that will be provided. Based on the SWOT methodology, the impact of the MRO outsourcing model was investigated using the perspective of each stakeholder (Aircraft OEMs, Repair Shops, System Suppliers and Airlines). This exercise showed strong competition between stakeholders due to the relevant number of players. Concurrently, the analysis indicated there is a tendency of the market to build partnerships between stakeholders to expand market penetration. Additionally, the concept "one stop shop" was identified, meaning that the customer is looking for only one place to overhaul the aircraft.

\section{REFERENCES}

[1] EFNMS. 2013. "MRO Definition". European Federation of National Maintenance Society. http://www.efnms.org/

[2] Kinnison, H. A. 2012. "Aviation Maintenance Management". McGraw-Hill, New York, NY.

[3] Viles, E,, Puente, D., Alvarez, M. J. and Alonso, F. 2007. "Improving the corrective maintenance of an electronic system for trains". Journal of Quality in Maintenance Engineering, Vol. 3, pp. 75-87.

[4] Randall, W. S., Pohlen, T. L. and Hanna J. B. 2010 "Evolving a Theory of Performance Based Logistics Using Insights from Service Dominant Logic". Journal of Business Logistics, Vol. 31 (2): 35-62.

[5] Safaei, N., Banjevic, D. and Jardine, A. 2011. "Workforce-constrained maintenance scheduling for military aircraft fleet: A case study". Published online: 17 May 2011, Springer Science+Business Media, LLC.

[6] Shafiee, M. and Chukova, S. 2013. "Maintenance models in warranty: A literature review". European Journal of Operational Research, Vol. 229: 561-572.

[7] IATA. 2009. "Overhauling Maintenance, Repair and Overhaul http://www.iata.org/publications/airlines-

(MRO)". international/december-2009/Pages/08.aspx (accessed 10 February 2014)

[8] AW\&ST. 2013. "The MRO global leading players". Aviation Week and Space Technology, MRO Edition, Aviation Week Ranks. April 2013.

[9] PIPAME. 2010. "Le pôle interministériel de prospective et d'anticipation des mutations économiques, Maintenance et Réparation Aéronautique". Base de connaissances et évolution, available at: http://www.dgcis.gouv.fr/files/files/directions_services/et udes-et-

statistiques/etudes/aeronautique_maintenance/aeronautiq ue_maintenance.pdf

[10] Phillips, P., Diston, D. and Starr, A. 2011. "Perspectives on the commercial development of landing gear health monitoring systems". Transportation Research. Part C (19): 1339-1352.

[11] McFadden, M. and Scott Worrells, D. 2012. "Global Outsourcing of Aircraft Maintenance". Journal of Aviation Technology and Engineering.

[12] CIMdata. 2002. "Product lifecycle management: Empowering the future of business". Ann Arbor, MI http://doc.mbalib.com/view/8cb8b763acd25742ed7e72ad 9ac29d01.html

[13] Marais, K. and Robichaud, M. 2012. "Analysis of trends in aviation maintenance risk: An empirical approach, Reliability Engineering and System Safety". School of Aeronautics and Astronautics, Purdue University, West Lafayette, IN.(accessed 10 April 2014).

[14] Carpenter, R., \& Henderson, A. "Keep Them Flying: Find your winning position in the MRO game. IBM Global Business Services: http://www304.ibm.com/jct03004c/easyaccess/fileserve?contentid=1 74266 
[15] Yoon, K.P. and Naadimuthu, G. 1994. "A make-or-buy decision analysis involving imprecise data". International Journal of Production Management, Vol. 14 (2): 62-69.

[16] Aviation Safety Bureau. 2013. http://www.aviationsafety-bureau.com/aircraft-maintenance.html

[17] Miroux, F. Y. J. 2012. "How to get a sustainable maintenance spare parts management?" Thesis, Master of Science in Operations Management and Logistics, TU/e

[18] Karadžic, R., Petkovic, D. and Šabic, M. 2012. "A model for the maintenance of old aircraft". Aviation, ISSN 1648-7788 (Print), 1822-4180.

[19] Bales, R. R., Maull, R. S. and Radnor, Z. 2004. "The development of supply chain management within the aerospace manufacturing sector". Supply Chain Management, Vol. 9 (3): 250-255.

[20] Raju, V. R. S., Gandhi, O. P. and Deshmukh, S. G. 2012. "Maintenance, Repair, and overhaul Performance Indicators for Military Aircraft". Defence Science Journal, Vol. 62 (2): 83-89, DESIDOC.

[21] Boeing. 2013. "Current Market Outlook 2013 - 2032". www.boeing.com/assets/.../Boeing_Current_Market_Out look_2013.pdf

[22] Bombardier. 2013. "Market Forecast 2013 - 2032". http://ir.bombardier.com/var/data/gallery/document/34/2 4/25/71/13/Bombardier-aerospace-2013-2032-BCABBA-Market-Forecast.pdf

[23] Patterson, Jr., L. and Tonder, V. 2009. "External Strategic Analysis of the Aviation Maintenance, Repair and Overhaul (MRO), Industry and Potential Market Opportunities for Fleet". Readiness Center Southwest, Naval Postgraduate School, MBA Professional Report.

[24] Research MOZ. 2013. "The Global Military Aircraft Market 2013-2023". http://www.researchmoz.us/.

[25] Chrisman, H. (2008, April). The PBL debate: An Overview of the Global Military. Aircraft MRO Market.

[26] Défense National du Canada. 2013. "Capacité de la prochaine génération de chasseurs mise à jour annuelle". http://www.forces.gc.ca/fr/a-propos-rapportspubs/prochaine-generation-chasseurs-maj-annuelle2013.page

[27] Cohen, M. A. and Wille, J. H. 2006. "Implications for Service Parts Management in the Rapidly Changing Aviation MRO Market".

[28] Almeida, C. 2005. "Low cost maintenance, repair and overhaul providers: an optimum balance to capture the low cost carriers market". MSc Thesis. Department of Air Transport School of Engineering.

[29] Rosenberg, B. 2004. "Everybody's doing it; airline maintenance strategies are diverse, but all include an element of outsourcing", Aviation Week, 19 April, p. 68.

[30] FAA, Federal Aviation Advisory. 2013. "Practices and Perspectives in Outsourcing Aircraft Maintenance". DOT/FAA/AR-02/122. Office of Aviation Research.

[31] Al-kaabi, H., Potter, A., Naim, M. 2007. "An outsourcing decision model for airlines' MRO activities". Reprinted with permission from Emerald Group Publishing Limited, originally published in Journal of Quality in Maintenance Engineering, Vol. 13 (3): 217-227, (C) Emerald Group Publishing Limited [2007], http://www.emeraldinsight.com/doi/abs/10.1108/135525 10710780258

[32] Prahalad, C. K. and Hamel, G. 1990. "The core competence of the corporation". Harvard Business Review, Vol. 68 (3): 79-90.

[33] Heikkila, J. and Cordon, C. 2002. "Outsourcing: A core or non-core strategic management decision?" Strategic Change, Vol. 11: 183-93.

[34] Collier, D. 2004. "Outsourced maintenance: An analysis. Overhaul \& Maintenance". VIII SITRAER: 39-41.

[35] Guimarães; J. E. Pécora Jr.; and Vieira, D. R. 2013. "Effectiveness of SLA Project with spare parts management: The case of a telecom equipment industry". Journal of Modern Project Management, Vol. 01 (2) 